Article

\title{
New Key Performance Indicators for a Smart Sustainable City
}

\author{
Minako Hara ${ }^{1, *}$, Tomomi Nagao ${ }^{1,+}$, Shinsuke Hannoe ${ }^{1,+}$ and Jiro Nakamura ${ }^{2,+}$ \\ 1 Nippon Telegraph and Telephone Corporation, 3-9-11, Midori-cho, Musashino-shi, Tokyo 180-8585, Japan; \\ nagao.tomomi@lab.ntt.co.jp (T.N.); hannoe.shinsuke@lab.ntt.co.jp (S.H.) \\ 2 NTT Advanced Technology Corporation, Kanagawa 212-0014, Japan; jiro.nakamura@ntt-at.co.jp \\ * Correspondence: hara.minako@lab.ntt.co.jp; Tel.: +81-422-59-2281; Fax: +81-422-59-5681 \\ + These authors contributed equally to this work.
}

Academic Editors: Matthias Finkbeiner, Masaharu Motoshita, Shinsuke Murakami, Yasushi Kondo and Yasuhiro Fukushima

Received: 30 September 2015; Accepted: 18 February 2016; Published: 3 March 2016

\begin{abstract}
We propose key performance indicators (KPIs) based on the Gross Social Feel-Good Index to evaluate a smart sustainable city and report the results of a field trial in a city located almost at the center of the Tokyo Metropolitan Area. We developed KPIs based on the following concepts: (1). The triple bottom line is the basic evaluation criteria; (2). The same unit is used for every evaluation criterion; (3). The KPIs can be used to assess a diverse range of smart sustainable cities with different goals. With the proposed KPIs of smart sustainable cities, indicators are divided into four layers for simplicity: the triple bottom line and "satisfaction" lie in the first layer. Since the notion of "society" is broad, it is further split into "safety", "health", and "comfort", which are positioned in the second layer. The third layer includes indicators such as "information security" and "ubiquitous society" from the perspective of information communication technology (ICT). We conducted a trial evaluation by applying the proposed KPIs to individual ICT solutions of "Internet Protocol announcements", "Wi-Fi around the station" and "information transmission and control" which have already been installed in a smart sustainable city.
\end{abstract}

Keywords: smart city; information communication technology (ICT); key performance indicators (KPIs)

\section{Introduction}

In 2014, the United Nations reported that $54 \%$ of the world's population was residing in urban areas [1]. In 1950, this figure was 30\%. The United Nations has predicted that $66 \%$ of the world's population will be urban by 2050. This concentration of population leads to urban and social problems.In Japan, emerging phenomena, such as the concentration of the population in urban areas, declining population in rural areas, and demographic change brought by the declining birthrate and aging society, have highlighted issues including energy consumption, economic inefficiency, and the deterioration of disaster prevention functionality. The challenges facing each country and city differ depending on the history, culture, and environment. A smart sustainable city (SSC), which is generally defined as integration of multiple technological solutions to improve the quality of life of the residents, is expected to tackle the issues that cities currently have or will have in the future such as security, infrastructure protection, property vacancy, traffic-related problems including traffic jams, traffic accidents as far as modal shift and EV charging infrastructure [2-10]. Information and communication technology (ICT) is desired to play crucial role in achieving successful SSCs [11,12].

However, there are some important literatures on so called smart cities. Holland suggests that we make more efficient use of physical infrastructure, such as roads, built environment and other physical 
assets through artificial intelligence and data analytics to support a strong and healthy economic, social, cultural development or else business-oriented model may result in a losing long term strategy and it is no longer "smart city" but "industrial" or "manufacturing city" [13]. Dameri mentioned that a shared and sound definition of smart city was still lacking, as well as a strategic vision to design long term strategies [14]. Deakin defined a smart city as one that utilizes ICTs to meet the demands of the market including the citizens of the city, and that community involvement in the process is necessary for a smart city [15]. Kumar mentioned that it is important to assess the impact of the Smart City and defined Smart City as a knowledge-based city that develops extraordinary capabilities to be self-aware, how it functions $24 \mathrm{~h}$ a day and 7 days a week and communicate, selectively, in real-time knowledge to citizen end users for satisfactory way of life with easy public delivery of services, comfortable mobility, conservation of energy, environmental and other natural resources and create energetic face to face communities and a vibrant urban economy even at a time there is bational economic downturns [16]. Kitchin critically pointed the shortcomings of the present smart city are the lack of detailed genealogies of the concept and initiatives, the use of canonical examples and one-size fits all narratives, an absence of in-depth empirical case studies of specific smart city initiatives and comparative research that contrasts smart city developments in different locales and weak collaborative engagement with various stakeholders [17]. Regarding these literatures, assessment methodology is necessary for the impact of a smart city and its technological solutions and a smart city and its technological solutions should improve the quality of life of residents and should meet the demands of market, which means citizens. Thus, the lack of a shared and sound definition and long term strategy of smart city is still an ongoing issue, we suppose that smart city and its technological solutions are more or less designed to improve the quality of life of residents directly or indirectly by mitigating the impact of current urban problems at least in short term.

Figure 1 shows international standardization activities on smart communities and cities. The International Organization for Standardization (ISO) created TC 268 "Sustainable development in Communities" and TC 268/SC 1 "Smart Community Infrastructures" in May 2012. The International Electrotechnical Commission also setup the System Evaluation Group 1 "Smart Cities" in June 2013. The Joint Technical Committee established a "Study Group on Smart Cities" in JTC 1 "Information Technology" in November 2013. The Telecommunication Standardization Sector in International Telecommunication Union (ITU-T) ran a focus group on SSCs from February 2013 to May 2015 [18]. it defines an SSC as follows: "[An] SSC is an innovative city that uses ICTs and other means to improve quality of life, efficiency of urban operation and services, and competitiveness, while ensuring that it meets the needs of present and future generations with respect to economic, social and environmental aspects". Therefore, any strategy aimed at making urban systems smarter and more sustainable should focus on ultimately improving the quality of life of the city's inhabitants through novel, more efficient, and increasingly inclusive ICT-enabled approaches. An SSC is designed to solve the issues faced by cities, and its ultimate goal is to improve the quality of life of its citizens. The definition of quality of life and a methodology for its assessment have been developed in many countries, and in most cases, the scope is based on the triple bottom line of environment, society, and economy. Therefore, the goal of the current study was to propose a new set of key performance indicators (KPIs) and assessment methodology for improvement and decrease of environment, society and economy with respect to the quality of life of citizens provided by technological solutions in SSCs based on the triple bottom line and to test the proposed KPIs through case studies of ICT solutions in SSC. 


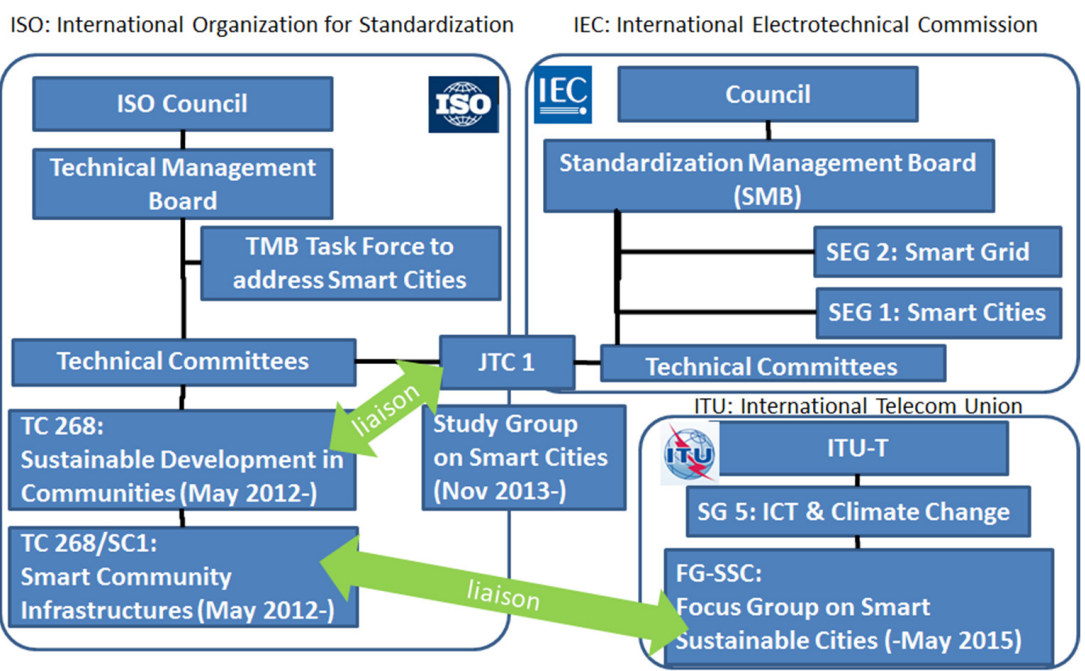

Figure 1. International standardization activities for a smart sustainable city (SSC).

\section{Method}

\subsection{KPI Setting}

Several papers have been published on the reduction of environmental burdens by the use of ICT [19-29]. Whereas the goals of SSCs vary according to the challenges they face, so do the KPIs in terms of assessing progress [30]. Therefore, the KPIs of such cities should be used to quantitatively measure the progress toward meeting the unique goals set by each city and provide feedback on policy and implementation. Assessing every SSC with a uniform set of KPIs and ranking them are not part of the original purpose. In addition, there are many possible evaluation axes for the KPIs of such cities, as shown in Table 1. If the KPI unit values on the evaluation axes are the same, it becomes easy to integrate them and create a single KPI for all SSCs. The KPIs are designed to assess progress with a view to meeting the goals set by each city. Such evaluation is conducted before, after, or during SSC policy implementation.

Table 1. Sub-dimensions of key performance indicators (KPIs) from ITU-T FG-SSC.

\begin{tabular}{|c|c|}
\hline Dimension & Sub-Dimensions \\
\hline Information and communication technology & $\begin{array}{l}\text { Network and access, Services and information platforms, } \\
\text { Information security and privacy, Electromagnetic field }\end{array}$ \\
\hline Environmental sustainability & $\begin{array}{l}\text { Air quality, Greenhouse gas (GHG) emissions, Energy, Indoor } \\
\text { pollution, Water, soil and noise }\end{array}$ \\
\hline Productivity & $\begin{array}{l}\text { Capital investment, Employment, Inflation, Trade, Savings, } \\
\text { Export/import, Household income/consumption, Innovation, } \\
\text { Knowledge economy }\end{array}$ \\
\hline Quality of life & $\begin{array}{l}\text { Education, Health, Safety/security public place, Convenience } \\
\text { and comfort }\end{array}$ \\
\hline Equity and social inclusion & $\begin{array}{l}\text { Inequity of income/consumption (Gini coefficient), Social and } \\
\text { gender inequity of access to services and infrastructure, } \\
\text { Openness and public participation, Governance }\end{array}$ \\
\hline Physical infrastructure & $\begin{array}{l}\text { Infrastructure/connection to services-piped water, } \\
\text { Infrastructure/connection to services-sewage, } \\
\text { Infrastructure/connection to services-electricity, } \\
\text { Infrastructure/connection to services-waste management, } \\
\text { Connection to services-knowledge infrastructure, } \\
\text { Infrastructure/connection to services-health infrastructure, } \\
\text { Infrastructure/connection to services-transport, } \\
\text { Infrastructure/connection to services-road infrastructure, } \\
\text { Housing-building materials, Housing-living space, Building }\end{array}$ \\
\hline
\end{tabular}


Taking these factors into consideration, we developed our proposed KPIs based on the following concepts, as shown in Table 2:

- The triple bottom line is the basic evaluation criteria.

- The same unit is used for every evaluation criterion.

- $\quad$ The KPIs can be used to measure a diverse range of SSCs with different goals.

Table 2. Structure of proposed KPIs.

\begin{tabular}{|c|c|c|c|}
\hline $\begin{array}{l}\text { 1st Layer (Unit: } \\
\text { Monetary Value) }\end{array}$ & $\begin{array}{l}\text { 2nd Layer (Unit: } \\
\text { Monetary Value) }\end{array}$ & $\begin{array}{l}\text { 3rd Layer (Unit: } \\
\text { Monetary Value) }\end{array}$ & $\begin{array}{l}\text { 4th Layer Examples (Unit: Monetary } \\
\text { Value, \%, Time, Weight, etc.) }\end{array}$ \\
\hline \multirow[b]{2}{*}{ Environment } & \multirow[b]{2}{*}{ Environment } & $\begin{array}{l}\text { Environment/natural } \\
\text { resource }\end{array}$ & $\begin{array}{l}\text { Amount of GHG emissions, waste, } \\
\text { resource depletion (water, underground } \\
\text { resources etc.), toxic substances, } \\
\text { biodiversity }\end{array}$ \\
\hline & & Energy & $\begin{array}{l}\text { Resource depletion, amount of } \\
\text { consumption, sustainability of } \\
\text { electricity supply, utilization rate of } \\
\text { renewable energy }\end{array}$ \\
\hline Economy & Economy & Cost performance & $\begin{array}{l}\text { Cost: deployment, operation, } \\
\text { maintenance, benefit: financial effect, } \\
\text { profit, employment rate, enterprising } \\
\text { rate, online billing rate }\end{array}$ \\
\hline \multirow{12}{*}{ Society } & \multirow{4}{*}{ Safety } & Accident & $\begin{array}{l}\text { Accident rate (victims, damaged } \\
\text { objects), damage cost }\end{array}$ \\
\hline & & Natural disaster & $\begin{array}{l}\text { Damage rate (victims, damaged } \\
\text { objects), damage cost }\end{array}$ \\
\hline & & Crime & $\begin{array}{l}\text { Damage rate (victims, damaged } \\
\text { objects), damage cost }\end{array}$ \\
\hline & & Information security & $\begin{array}{l}\text { Information accessibility, information } \\
\text { leakage rate, information importance, } \\
\text { damage cost }\end{array}$ \\
\hline & \multirow{4}{*}{ Health } & Health management & $\begin{array}{l}\text { activity level, nursing care cost, social } \\
\text { security cost }\end{array}$ \\
\hline & & Prevention of illness & $\begin{array}{l}\text { Morbidity (incidence rate, prevalence, } \\
\text { fatality rate), medical expenses }\end{array}$ \\
\hline & & Medical treatment & Mortality, morbidity, medical expenses \\
\hline & & Stress & Morbidity, medical expenses \\
\hline & \multirow{4}{*}{ Comfort } & Diverse opportunities & $\begin{array}{l}\text { Labor force participation rate, number } \\
\text { of tourists, frequency of visit, purchase } \\
\text { rate, leisure time, means of } \\
\text { transportation }\end{array}$ \\
\hline & & Barrier free & $\begin{array}{l}\text { Usage ratio (number of people, } \\
\text { frequency), user demographics }\end{array}$ \\
\hline & & Simplicity & $\begin{array}{l}\text { Usage ratio (number of people, } \\
\text { frequency), willingness to use, } \\
\text { satisfaction level with equipment }\end{array}$ \\
\hline & & Ubiquitous & $\begin{array}{l}\text { Service area, service penetration ratio, } \\
\text { service duration }\end{array}$ \\
\hline Satisfaction & Satisfaction & $\begin{array}{l}\text { Citizens' degree of } \\
\text { satisfaction }\end{array}$ & Willingness to pay \\
\hline
\end{tabular}

As the basis of the proposed KPIs, which satisfy the above concepts, we used the Gross Social Feel-Good (GSF) index. In GSF, six indicators are proposed: "environment", "economy", "comfort", "health", "safety", and "satisfaction". With the proposed KPIs of an SSC, the indicators are divided into four layers for simplicity, and the triple bottom line and "satisfaction" are positioned as the first layer. 
Since the notion of "society" is broad, it is further split into "safety", "health", and "comfort," and positioned in the second layer. The third layer includes indicators such as "information security" and "ubiquity" from the perspective of ICT. The fourth layer includes the data needed to calculate the KPIs in the third layer. In the first layer, "environment" and "economy" are referred to as requisite KPIs in every SSC, and "society" is selected according to the goals of the SSC. In addition, "environment" is evaluated from both the operator's and citizens' perspective; "economy" is evaluated from the operator's perspective, and "society" and "satisfaction" are evaluated from the citizens' perspective. The main feature of the KPIs is that various units are used for the data in the fourth layer, as we indicate in the table below, while all the other layers use monetary values as the unit. The data in the fourth layer, which uses units other than a monetary value, are as shown in this example and converted into a monetary value in the third layer using a conversion factor generated based on various statistical data. Thus, these are different from the dimension contents of the KPIs of ITU-T FG-SSC, the contents of each layer from the proposed KPIs cover most of the quantitative contents.

As described above, the results of the proposed KPIs, except in the fourth layer, use the same monetary unit. One possible method for integrating the values to create a single indicator is by weighting and adding them. However, because the degree of weighting allocated to different criteria depends on the goals of the SSC and the values provided by the citizens, making a decision on the basis of a single interpretation is problematic. This issue requires further consideration.

\subsection{Case Analysis}

We implemented three case studies of assessment on improvement and decrease of environment, society and economy provided by individual ICT solutions deployed in SSCs to confirm the effectiveness of the proposed KPIs. As is happening in suburbs in Japan, commercial districts in Mitaka city that were initially created for shopping are disappearing or not functioning because the number of shops in the area is decreasing or the shops cannot keep their cohesiveness as a commercial district. There is also the concern that the number of consumers who have difficulties in shopping for food and daily commodities may increase due to the aging society and decrease in the functioning of the local community. Given this situation, actions to increase the profitability of commercial districts and activation of commercial districts are necessary, as well as services to increase convenience, safety, and security, i.e., delivery, picking-up and dropping-off, and remote watching service.

Located 48 kilometers to the west of Tokyo metropolitan area and lying almost at the center of Tokyo prefecture, Mitaka city is one of the most popular residential districts in Japan with rural charm and educational institutions. Mitaka city has a regional characteristic of large population during day and night with a population of one hundred and eighty thousand; about two hundred thousand passengers use Mitaka station daily. Therefore, the disaster prevention steps of the local government may not be sufficient for such a diverse community including local residents, workers, students and tourists, and this may make it difficult for many people to go home after a disaster. In addition, the rapid aging society and the increasing number of elderly living alone and people in need of support are serious problem. It is necessary to create a new platform to promote more active local cooperation considering the experience from the Great East Japan Earthquake. To solve these problems, the following platform becomes an urgent requirement to improve the disaster resilience of local communities; providing precise information of the disaster situation and immediate evacuation via diverse media using the minimum amount of manpower and time; confirming safety in time and collecting information of people in need of support for evacuation; sharing this information with the people who are able to support people in need.

The case studies discussed in this paper aim to solve these serious problems that local communities are suffering. All the studies were conducted in February and March 2013. The number of users or beneficiaries that participated in the studies varied greatly according to the service. 


\subsubsection{IP Announcements}

As the result of society aging, more households consist of just the elderly (singles and couples). A local support system is needed to prevent social problems such as solitary death. Specifically, a support system for local shops and communities to look after the elderly is necessary. Smartphones and tablets are becoming popular, but quite a few of the elderly have yet to surmount the digital divide and their information medium is often limited to papers or flyers. "Internet Protocol (IP) announcements" were designed to connect people in a local society via tablet terminals with an easy GUI. Figure 2 shows the network structure of "IP announcements" with the following functions.

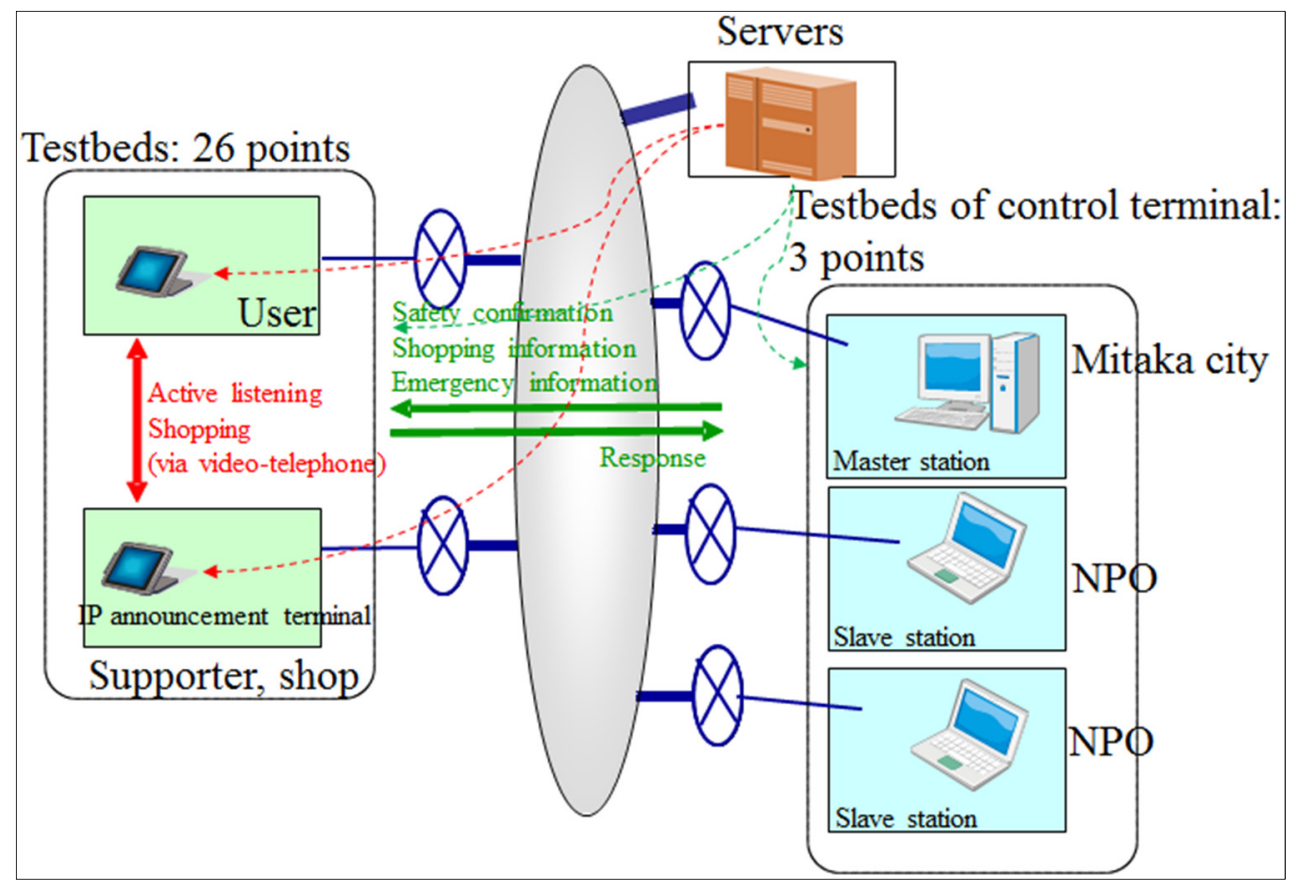

Figure 2. Network structure of IP announcements.

\section{It supports}

- Confirmation of resident's daily safety, i.e., elderly living alone, by sending a message of safety confirmation and receiving a response.

- Active listening by counselor from nonprofit organization using video telephone aims to determine early signs of physical, psychological, and living problems

- Remote shopping using video telephony and delivery service provided by local shops for people in need of support, i.e., elderly living alone, handicapped, and expectant mothers. Shopping information is available via a tablet using information sent from local shops

This system is also useful after a disaster. The local government can send emergency information to confirm the safety of residents and support seamless evacuation.

In this study, ten support requesters including five elderly living alone and five people that find daily shopping difficult, such as the elderly and expectant mothers, ten supporters for each support requester, three local shops, and one Community Comprehensive Support Center participated in the IP announcements. All participants used android-based tablet terminals that were connected to a public optical network. Mitaka city sent e-mails for safety confirmation once a day during the experiment. Improved efficiency in safety confirmation and active listening and improved satisfaction and peace of mind were assessed by collecting data and questionnaire responses before and after the study. Mitaka city also provided shopping information to support requesters several times during 
the experiment. Supporters visited support requesters about once a week to inquire whether the information distribution was useful for shopping assistance.

Table 3 shows the assessed items for the announcement system.

Table 3. Assessed items of IP announcements.

\begin{tabular}{|c|c|c|c|}
\hline $\begin{array}{l}\text { 1st Layer (Unit: } \\
\text { Monetary Value) }\end{array}$ & $\begin{array}{l}\text { 2nd Layer (Unit: } \\
\text { Monetary Value) }\end{array}$ & $\begin{array}{l}\text { 3rd Layer (Unit: } \\
\text { Monetary Value) }\end{array}$ & $\begin{array}{l}\text { 4th Layer Examples } \\
\text { (Unit: Monetary Value, } \\
\text { \%, Time, Weight, etc.) }\end{array}$ \\
\hline \multirow[t]{2}{*}{ Environment } & \multirow[t]{2}{*}{ Environment } & $\begin{array}{l}\text { Environment/Natural } \\
\text { resources }\end{array}$ & \multirow{2}{*}{$\begin{array}{l}\text { GHG emissions from ICT } \\
\text { system }\left(\mathrm{kg}-\mathrm{CO}_{2} \mathrm{e}\right)\end{array}$} \\
\hline & & Energy & \\
\hline Economy & Economy & Cost performance & $\begin{array}{l}\text { Construction/Operation } \\
\text { cost of ICT system } \\
\text { Car fuel cost }\end{array}$ \\
\hline \multirow{12}{*}{ Society } & \multirow{4}{*}{ Safety } & Accident & $\begin{array}{l}\text { Decrease in damage cost } \\
\text { due to traffic accidents }\end{array}$ \\
\hline & & Natural disaster & - \\
\hline & & Crime & Damage cost due to theft \\
\hline & & Information security & - \\
\hline & \multirow{4}{*}{ Health } & Health management & - \\
\hline & & Prevention of illness & - \\
\hline & & Medical treatment & - \\
\hline & & Stress & - \\
\hline & \multirow{4}{*}{ Comfort } & Diverse opportunities & $\begin{array}{l}\text { Revenue from decrease } \\
\text { in shopping time }\end{array}$ \\
\hline & & Barrier free & - \\
\hline & & Simplicity & - \\
\hline & & Ubiquitous & - \\
\hline Satisfaction & Satisfaction & $\begin{array}{l}\text { Citizen's degree } \\
\text { of satisfaction }\end{array}$ & $\begin{array}{l}\text { Willingness to pay } \\
\text { for service }\end{array}$ \\
\hline
\end{tabular}

\subsubsection{Wi-Fi around Station}

At the time of the Great East Japan Earthquake, Mitaka city was also in disorder, and disaster information was provided mainly via mobile phones. Immediately after the earthquake, people had difficulty going home with almost no way of obtaining information; most gathered around Mitaka station. This created heavy traffic concentrations in the mobile cellular network and urgent communication became impossible during the disaster due to the sheer number of mobile phones. Most visitors from outside Mitaka city had only mobile phones as their communication device. It is essential to ensure the communication of necessary information by preventing or reducing cellular traffic concentrations. Considering this experience, Mitaka city prepared a wireless communication environment using "Wi-Fi around station", as an experiment aiming to support people trying to go home. It offers precise information even during traffic congestion and disorder after or during a disaster. This case study involved a communication service that enables Wi-Fi terminal users, i.e., smartphone users around Mitaka station, to learn of the situation and information about disaster prevention and the evacuation of Mitaka city.

"Wi-Fi around station" was also designed to activate the commercial district around Mitaka station. In collaboration with commercial districts and shops in the Wi-Fi area, Mitaka city provides flyers, electronic coupons, and event information aiming to increase the number of visitors and stimulate economic activity.

Figure 3 shows the network structure of "Wi-Fi around station". Wi-Fi access points were set up around Mitaka station. Mitaka city center provides information on commercial districts and shops via 
its portalsite. Visitors around the station can access the Internet for free after logging into Mitaka city center. In this case study, Mitaka city center collected user information and accessed logs for analysis. During a disaster, visitors can link to disaster information without certification.

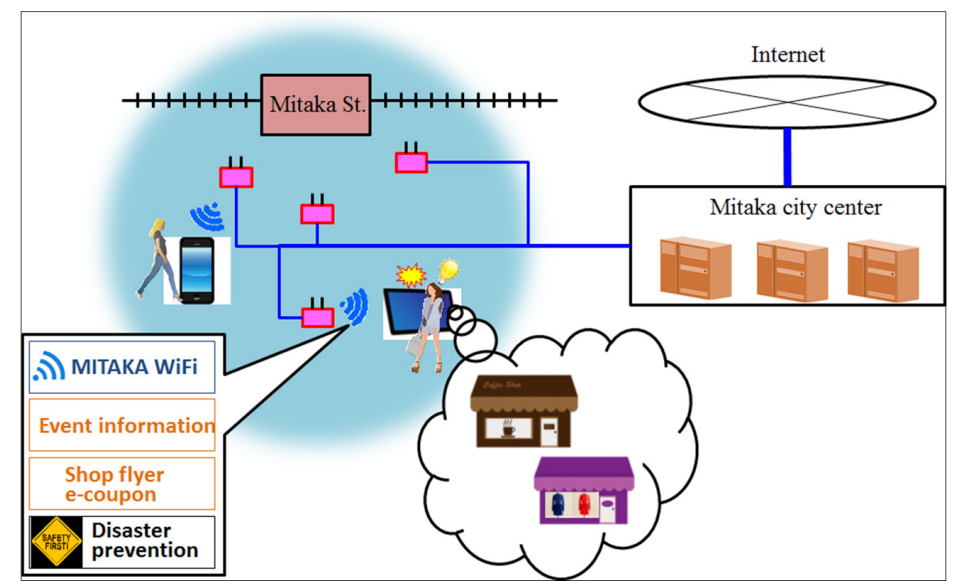

Figure 3. Network structure of "Wi-Fi around station".

In this study, four Wi-Fi access points were set at a bus rotary to cover the area around Mitaka station. The portal site of this Wi-Fi experiment counted the number of users from the access logs. This study also encouraged the shops in the Wi-Fi area to advertise themselves using electric advertisements and electric coupons in the portal site. The impact of advertisements was assessed by the number of shop visitors before and after the study by conducting questionnaires at each shop. A disaster prevention drill was also virtually simulated. The portal site was switched to emergency mode by triggering a sensor function. The number of participants in the drill was counted via the access logs. The efficiency of the drill was measured from questionnaire results.

Table 4 lists the items assessed for the announcement system.

Table 4. Assessed items of "Wi-Fi around station".

\begin{tabular}{|c|c|c|c|}
\hline $\begin{array}{l}\text { 1st Layer (Unit: } \\
\text { Monetary Value) }\end{array}$ & $\begin{array}{l}\text { 2nd Layer (Unit: } \\
\text { Monetary Value) }\end{array}$ & 3rd Layer (Unit: Monetary Value) & $\begin{array}{l}\text { 4th Layer Examples (Unit: Monetary } \\
\text { Value, \%, Time, Weight, etc.) }\end{array}$ \\
\hline \multirow{2}{*}{ Environment } & \multirow{2}{*}{ Environment } & Environment/Natural resources & \multirow{2}{*}{ GHG emissions from ICT system $\left(\mathrm{kg}-\mathrm{CO}_{2} \mathrm{e}\right.$} \\
\hline & & Energy & \\
\hline Economy & Economy & Cost performance & $\begin{array}{l}\text { Operation cost of ICT system } \\
\text { Increased sales revenue of shopping district }\end{array}$ \\
\hline \multirow{12}{*}{ Society } & \multirow{4}{*}{ Safety } & Accident & - \\
\hline & & Natural disaster & - \\
\hline & & Crime & - \\
\hline & & Information security & - \\
\hline & \multirow{4}{*}{ Health } & Health management & - \\
\hline & & Prevention of illness & - \\
\hline & & Medical treatment & - \\
\hline & & Stress & - \\
\hline & \multirow{4}{*}{ Comfort } & Diverse opportunities & $\begin{array}{l}\text { Revenue from decrease in time to recover } \\
\text { from communication congestion }\end{array}$ \\
\hline & & Barrier free & - \\
\hline & & Simplicity & - \\
\hline & & Ubiquitous & - \\
\hline Satisfaction & Satisfaction & Citizen's degree of satisfaction & Willingness to pay for service \\
\hline
\end{tabular}




\subsubsection{Information Transmission and Control}

Mitaka city is distributing disaster information using radio communication, the city's portal site, twitter, cable television, and early warning alerts, notices, and messages sent to mobile phones. "Information transmission and control" enables Mitaka city to provide appropriate information simultaneously through a variety of media including IP announcements during an emergency or disaster. "Information transmission and control" also enables information distributers to select suitable distribution media from a variety of media supported including IP announcements with smooth distribution in regular situations.

Figure 4 shows the concept of information transmission and control. The local government can distribute information using a wide variety of media. Users can receive information via several kinds of terminals regardless of whether they are inside buildings or outside.

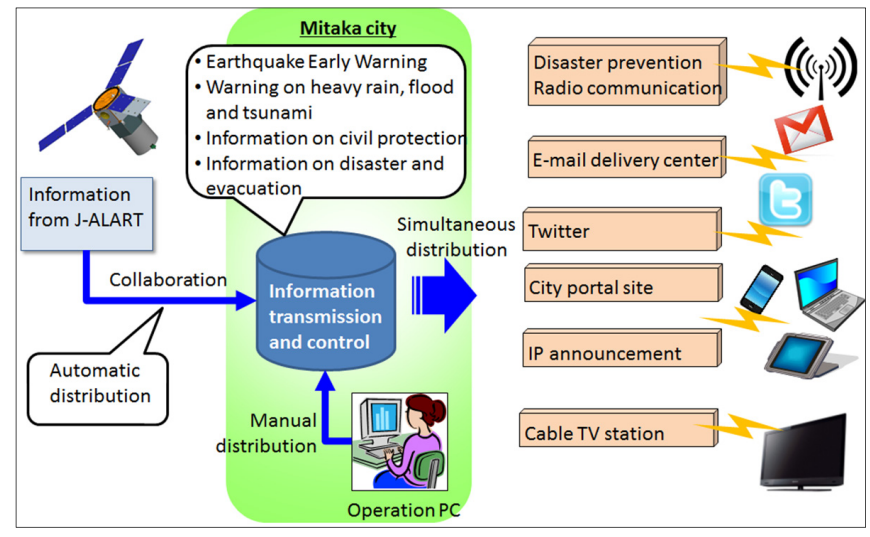

Figure 4. Concept of "Information transmission and control".

The improved efficiency of information transmission and control was assessed by comparing the necessary time and manpower for information distribution with and without Information transmission and control. A questionnaire was submitted to operators to investigate issues in detail. A total of 166,284 people participated in information transmission and control, which is the daytime population of Mitaka city.

Table 5 lists the items assessed for the announcement system.

Table 5. Assessed items of information transmission and control.

\begin{tabular}{|c|c|c|c|}
\hline $\begin{array}{l}\text { 1st Layer (Unit: } \\
\text { Monetary Value) }\end{array}$ & $\begin{array}{l}\text { 2nd Layer (Unit: } \\
\text { Monetary Value) }\end{array}$ & 3rd Layer (Unit: Monetary Value) & $\begin{array}{l}\text { 4th Layer Examples (Unit: Monetary } \\
\text { Value, \%, Time, Weight, etc.) }\end{array}$ \\
\hline Environment & Environment & $\begin{array}{l}\text { Environment/Natural resources } \\
\text { Energy }\end{array}$ & $\begin{array}{l}\text { GHG emissions from ICT system } \\
\qquad\left(\mathrm{kg}-\mathrm{CO}_{2} \mathrm{e}\right)\end{array}$ \\
\hline Economy & Economy & Cost performance & $\begin{array}{l}\text { Construction/Operation cost of ICT } \\
\text { system }\end{array}$ \\
\hline \multirow{3}{*}{ Society } & Safety & $\begin{array}{l}\text { Accident } \\
\text { Natural disaster } \\
\text { Crime } \\
\text { Information security }\end{array}$ & $\begin{array}{l}\text { Decrease in evacuation time } \\
- \\
- \\
-\end{array}$ \\
\hline & Health & $\begin{array}{l}\text { Health management } \\
\text { Prevention of illness } \\
\text { Medical treatment } \\
\text { Stress }\end{array}$ & $\begin{array}{l}- \\
- \\
-\end{array}$ \\
\hline & Comfort & $\begin{array}{l}\text { Diverse opportunities } \\
\text { Barrier free } \\
\text { Simplicity } \\
\text { Ubiquitous }\end{array}$ & $\begin{array}{l}- \\
- \\
- \\
-\end{array}$ \\
\hline Satisfaction & Satisfaction & Citizen's degree of satisfaction & Willingness to pay for service \\
\hline
\end{tabular}




\section{Results and Discussion}

For the environment layer, the estimation target was set based on the greenhouse gas (GHG) emissions in the three cases. The GHG emissions from the construction and operation of the ICT system were estimated using life cycle assessment (LCA). The original estimation was based on Japanese yen (JPY) because we acquired the necessary data from Japanese statistics. In this paper, the estimated value was converted to USD [\$] at the rate of $100 \mathrm{JPY}$ per USD.

\subsection{IP Announcements}

We considered three servers, including one control terminal, 2 PCs used as subsidiary control terminals, and 26 tablet terminals. We used EPSON/ Endeavor AT980E as the servers, NEC/VersaPro VJ20E/D-B as the PCs, and NTT-EAST/Flet's phone VP2000 as the tablets. The lifetimes of the servers, PCs, and tablets were assumed to be five, four, and seven years, respectively. The GHG emissions from their manufacture were estimated using the process LCA data, Those from their operation were estimated using rated power, and those from their disposal were estimated using Japanese I-O table values on waste treatment. The GHG emissions from their manufacture and disposal were allocated considering their lifetimes. Table 6 shows LCA results of the ICT system for IP announcements. Annual electricity consumption and GHG emissions of the ICT system for IP announcements was estimated to be $1295 \mathrm{kWh}$ /year and $762 \mathrm{~kg}-\mathrm{CO}_{2} \mathrm{e} /$ year, respectively, considering product life cycles.

Table 6. Annual GHG emissions from ICT system for IP announcements $\left(\mathrm{kg}-\mathrm{CO}_{2} \mathrm{e} /\right.$ year$)$.

\begin{tabular}{ccccc}
\hline & Manufacture & Operation & Disposal & Total \\
\hline Server & 57.5 & 383.3 & -7.9 & 433.0 \\
PC & 35.3 & 151.9 & 0.1 & 187.3 \\
Tablet & 16.5 & 125.1 & 0.0 & 141.7 \\
Total & 109 & 660 & -8 & 762 \\
\hline
\end{tabular}

The decrease in damage cost (fewer traffic accidents) yielded by shopping assistance was estimated using Equation (1). Table 7 lists the parameters used and the calculated decreased damage cost of traffic.

Decrease in damage cost due to traffic accidents $=$

Probability of traffic accidents $\times$ User number $\times$ Human loss

Table 7. Parameters and calculation results of decreased damage cost of traffic accidents.

\begin{tabular}{lcl}
\hline \multicolumn{1}{c}{ Parameter } & Amount & \multicolumn{1}{c}{ Note } \\
\hline $\begin{array}{l}\text { Probability of traffic } \\
\text { accidents }\end{array}$ & $0.4 \%$ & $\begin{array}{l}\text { Annual number of traffic accident } \\
\text { victims in Mitaka city in 2011 [31] } \\
\text { divided by population of Mitaka city } \\
\text { on 1 January 2012 [32] }\end{array}$ \\
\hline Number of users & 10 & Assumption of study \\
\hline $\begin{array}{l}\text { Average human loss } \\
\text { D1.16 million/person }\end{array}$ & $\begin{array}{l}\text { Annual total human loss due to traffic } \\
\text { accidents in Japan divided by annual } \\
\text { number of traffic-accident victims in }\end{array}$ \\
\hline $\begin{array}{l}\text { Jecrease in damage cost } \\
\text { due to traffic accidents }\end{array}$ & $\$ 440 /$ year & Calculated using Equation (1) \\
\hline
\end{tabular}


To address the decrease in damage cost of crimes prevented by shopping assistance, we focused on actions such as bag-snatching. Decreased damage cost due to theft prevention was estimated using Equation (2).

Decrease in damage cost due to theft prevention $=$ Probability of theft $\times$ User number $\times$ Loss from theft

Table 8 lists the parameters and calculated decrease in damage cost due to theft prevention.

Table 8. Parameters and calculation results of decrease in damage cost due to theft prevention.

\begin{tabular}{|c|c|c|}
\hline Parameter & Amount & Note \\
\hline Probability of stealing & $0.7 \%$ & $\begin{array}{l}\text { Annual number of theft victims excluding } \\
\text { burglary in Mitaka city divided by } \\
\text { population of Mitaka city in } 2011 \text { [31] }\end{array}$ \\
\hline Number of users & 10 & Assumption of study \\
\hline Average loss due to theft & $\$ 920 /$ case & $\begin{array}{l}\text { Averaged annual monetary loss due to theft } \\
\text { in Japan } \\
\text { Note: Calculated from summation of total } \\
\text { monetary loss averaged by number of theft } \\
\text { cases [34]. }\end{array}$ \\
\hline $\begin{array}{l}\text { Decreased in damage cost due to } \\
\text { theft prevention }\end{array}$ & $\$ 28 /$ year & Calculated using Equation (2) \\
\hline
\end{tabular}

To address the impact on the economy, we focused on the increase and decrease in the cost of IP announcements. These costs were estimated and are listed in Table 9.

Table 9. Increase and decrease in costs of IP announcements.

\begin{tabular}{|c|c|c|c|}
\hline Increased/Decreased & Cost Category & $\begin{array}{l}\text { Annual Cost } \\
\text { (USD/Year) }\end{array}$ & Note \\
\hline Increased & System construction & 2483 & $\begin{array}{l}\text { Total cost of servers, PCs, and tablets } \\
\text { allocated by lifetime } \\
\text { Note: Assumed price was } \$ 396.9 \text { for } \\
\text { Endeavor AT980E, } \$ 746 \text { for } \\
\text { VJ20E/D-B, and } \$ 504 \text { for VP2000 }\end{array}$ \\
\hline Increased & Operation cost of Mitaka city & 192 & $\begin{array}{l}\text { Annual power consumption of } \\
\text { servers and PCs } \\
\text { Note: Assumed cost of electricity was } \\
\$ 0.16 / \mathrm{kWh}\end{array}$ \\
\hline Increased & Operation cost of users & 15 & $\begin{array}{l}\text { Annual power consumption of tablets } \\
\text { Note: Assumed price of electricity } \\
\text { was } \$ 0.16 / \mathrm{kWh}\end{array}$ \\
\hline Decreased & Fare for shopping & 71 & $\begin{array}{l}\text { Decreased bus fee for shopping } \\
\text { calculated by multiplying number of } \\
\text { elderly users (discounted bus fare) by } \\
\text { distribution rate of transportation } \\
\text { measures } \\
\text { Note: Bus fare was calculated based } \\
\text { on allocation of elderly passes. Bus } \\
\text { fare for shopping was assumed half } \\
\text { entire pass because main usage was } \\
\text { reported to be for shopping and going } \\
\text { to hospital }\end{array}$ \\
\hline
\end{tabular}

To assess the impact on comfort, we focused on the decrease in shopping time. The cost benefit was estimated using Equation (3). Table 10 lists the parameters and calculated results of decrease in shopping time. 
Table 10. Parameters and calculated results of decrease in shopping time.

\begin{tabular}{lll}
\hline \multicolumn{1}{c}{ Parameter } & \multicolumn{1}{c}{ Amount } & \multicolumn{1}{c}{ Note } \\
\hline Decrease in time per shopping trip & 23.64 min/shopping trip & {$[35]$} \\
Annual number of shopping trips & 123 times/year & {$[35]$} \\
Number of users & 10 & Assumption of study \\
Minimum hourly wage (Japan) & $\$ 7.8 / \mathrm{h}$ & Weighted average of local \\
Annual cost benefit & $\$ 3766 /$ year & minimum hourly wage in Japan \\
\hline
\end{tabular}

To examine the impact on user satisfaction, we focused on user "willingness-to-pay (WTP)" for IP announcements. User satisfaction was estimated using Equation (4). Table 11 lists the parameters used for calculating user satisfaction with IP announcements.

$$
\text { User satisfaction }=\text { Averaged WTP } \times \text { Number of users }
$$

Table 11. Parameters and calculation results of user satisfaction with IP announcements.

\begin{tabular}{ccl}
\hline Parameter & Amount & \multicolumn{1}{c}{ Note } \\
\hline Averaged WTP & $\$ 13.6 /$ month/user & $\begin{array}{l}\text { Average from online questionnaire } \\
\text { for 100 respondents during 19 and } \\
\text { 21 June 2013 }\end{array}$ \\
\hline Number of users & 10 & Assumption of study \\
\hline Annual user satisfaction value & $\$ 1633 /$ year & Calculated using Equation (4) \\
\hline
\end{tabular}

Figure 5 shows the estimated impact of IP announcements based on the second layer of the proposed KPIs and the baseline defined as status quo. Compared with the baseline, IP announcements were expected to offer the largest improvement in comfort, as much as $\$ 4000$, with the second largest improvement in satisfaction, around $\$ 2000$. The estimated value for safety improvement was less than \$1000; insignificant compared with comfort and satisfaction. On the other hand, the estimated negative value on the economy was nearly $\$ 3000$, whereas the negative value on environment was negligible compared to the economy value and other positive values. This means that IP announcements significantly impacted comfort, economy, and satisfaction. In addition, the summation value of all KPIs was around $\$ 3000$ in the positive. This result suggests that IP announcements have a positive impact of as much as $\$ 3000$ per year from the viewpoint of the triple bottom line.

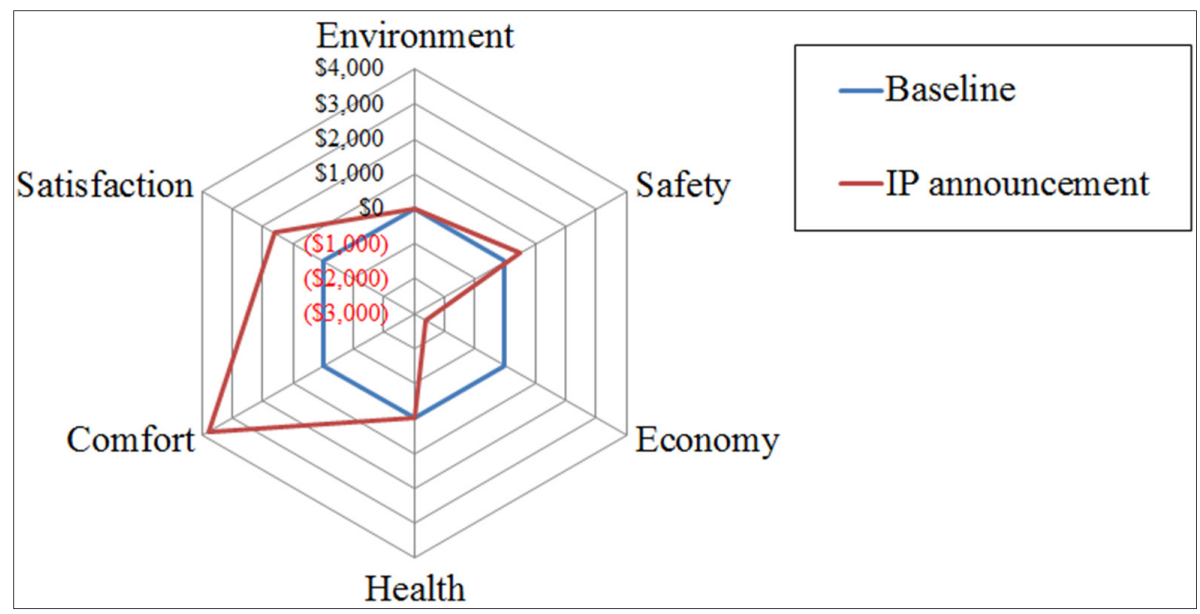

Figure 5. Estimated impact of IP announcements based on proposed KPIs. 


\subsection{Wi-Fi around Station}

We considered four wireless access points, one server, and three power over Ethernet (PoE) systems. We used two goNET MBW3100s and two WAVION WBS2400 Sectors as the wireless access points, and EPSON/Endeavor AT980E as the servers. The lifetimes of the wireless access points, PoEs, and server were assumed to be ten, ten, and five years, respectively. The GHG emissions from the manufacturer of access points and PoEs were estimated based on I-O analysis using Japanese I-O table values and prices and those from the manufacture of the server was estimated using the process LCA data. The GHG emissions from their operation were estimated using rated power, and those from their disposal were estimated using Japanese I-O table values of waste treatment. The GHG emissions from their manufacture and disposal were allocated considering their lifetimes. Table 12 lists the LCA results of the ICT system of Wi-Fi around station. The annual GHG emissions of this ICT system were estimated to be $902 \mathrm{~kg}-\mathrm{CO}_{2} \mathrm{e} /$ year considering product life cycles.

Table 12. Annual GHG emissions of ICT system for Wi-Fi around station $\left(\mathrm{kg}-\mathrm{CO}_{2} \mathrm{e} /\right.$ year$)$.

\begin{tabular}{ccccc}
\hline & Manufacture & Operation & Disposal & Total \\
\hline Access points (goNET MBW3100) & 83.9 & 187.6 & 0.24 & 272 \\
Access points (WAVION WBS2400 & 83.9 & 156.4 & 0.21 & 240 \\
Sector) & 30.8 & 151.9 & 0.14 & 245 \\
PoEs & 19.2 & 127.8 & -2.6 & 144 \\
Server & 217 & 686 & -2.0 & 902 \\
Total & &
\end{tabular}

To consider the impact on the economy, we focused on the costs and benefits of Wi-Fi around station. Costs were estimated, as shown in Table 13. Benefits were estimated to outweigh the costs of Wi-Fi around station.

Table 13. Costs and benefits of Wi-Fi around station.

\begin{tabular}{|c|c|c|c|}
\hline Increased Cost/Benefit & Category & $\begin{array}{c}\text { Annual Cost/Benefit } \\
\text { (USD/Year) }\end{array}$ & Note \\
\hline Increased cost & $\begin{array}{l}\text { System } \\
\text { construction }\end{array}$ & 885 & $\begin{array}{l}\text { Total cost of access points, PoEs, } \\
\text { and server allocated by lifetime } \\
\text { Note: Assumed cost was } \$ 1680 \text { for } \\
\text { goNET MBW3100 and WAVION } \\
\text { WBS2400 Sector, } \$ 446 \text { for PoEs, } \\
\text { and } \$ 396.9 \text { for EPSON/ Endeavor } \\
\text { AT980E }\end{array}$ \\
\hline Increased cost & Operation cost & 170 & $\begin{array}{l}\text { Annual power consumption by } \\
\text { access points, PoEs, and server } \\
\text { Note: Assumed cost of electricity } \\
\text { was } \$ 0.16 / \mathrm{kWh}\end{array}$ \\
\hline Increased benefit & $\begin{array}{l}\text { Increased } \\
\text { revenue }\end{array}$ & 2433 & $\begin{array}{l}\text { Increased revenue was calculated } \\
\text { by multiplying user number of } \\
\text { coupon by average consumption } \\
\text { by restaurants } \\
\text { Note: Assumed average } \\
\text { consumption by restaurants was } \\
\$ 20 \text { per person and annual } \\
\text { number of users was assumed to } \\
\text { be } 122 \text { based on study results }\end{array}$ \\
\hline
\end{tabular}


To examine the impact on comfort, we focused on the decrease in time spent in communication congestion. The cost benefit of this decrease was estimated using Equation (5). Table 14 lists the parameters and calculation results of decrease in time spent in communication congestion.

Cost benefit of decreased time spent in congestion $=$ Decreased time $\times$ Minimum hourly wage

Table 14. Parameters and calculation results of decrease in time of spent congestion.

\begin{tabular}{lll}
\hline \multicolumn{1}{c}{ Parameter } & \multicolumn{1}{c}{ Amount } & \multicolumn{1}{c}{ Note } \\
\hline Time per congestion & $80 \mathrm{~min} /$ shopping trip & $\begin{array}{l}\text { Based on assumption that it takes } 80 \mathrm{~min} \\
\text { to receive e-mail in case of strong } \\
\text { earthquake }\end{array}$ \\
\hline $\begin{array}{l}\text { Annual possible number of strong } \\
\text { earthquakes }\end{array}$ & 0.1 times/year & $\begin{array}{l}\text { Annual possible number of earthquakes } \\
\text { in Tokyo that measure more than five on } \\
\text { the Japanese earthquake intensity scale of } \\
\text { one to seven } \\
\text { Note: There was only one earthquake that } \\
\text { measured more than five in Tokyo in last } \\
\text { ten years [36] }\end{array}$ \\
\hline Number of users & 500 & $\begin{array}{l}\text { Assumption of the experiment } \\
\text { Minimum hourly wage (Japan) }\end{array}$ \\
\hline Annual cost benefit & $\$ 7.8 / \mathrm{h}$ & $\begin{array}{l}\text { Weighted average of local minimum } \\
\text { hourly wage in Japan in 2014 [37] }\end{array}$ \\
\hline
\end{tabular}

To consider the impact on user satisfaction, we focused on the user WTP for Wi-Fi around station. User satisfaction was estimated from Equation (4). Table 15 lists the parameters and calculation results of user satisfaction with Wi-Fi around station.

Table 15. Parameters used and calculation result of users' satisfaction with Wi-Fi around station.

\begin{tabular}{lcl}
\hline \multicolumn{1}{c}{ Parameter } & Amount & \multicolumn{1}{c}{ Note } \\
\hline Average WTP & $\$ 3.6 /$ month/user & $\begin{array}{l}\text { Obtained from questionnaire } \\
\text { Note: Refer to Table 11 }\end{array}$ \\
\hline Number of users & 500 & Assumption of study \\
\hline Annual users' satisfaction value & $\$ 21,570 /$ year & Calculated using Equation (4) \\
\hline
\end{tabular}

Figure 6 shows the estimated impact of Wi-Fi around station based on the second layer of the proposed KPIs and the baseline defined as status quo. Compared with the baseline, Wi-Fi around station was expected to offer the largest improvement in satisfaction, as much as $\$ 20,000$, and second largest improvement in the economy, around $\$ 1000$. The estimated improvement in comfort was less than $\$ 1000$, which was not significant compared with satisfaction and economy. On the other hand, the estimated negative impact on environment was negligible compared to the satisfaction value and other positive values. This means that the impact of Wi-Fi around station was significant in terms of satisfaction and economy. In addition, the summation value of all KPIs was around $\$ 3000$ in the positive. This suggests that $\mathrm{Wi}-\mathrm{Fi}$ around station has a positive impact of as much as $\$ 23,000$ per year from the viewpoint of the triple bottom line. 


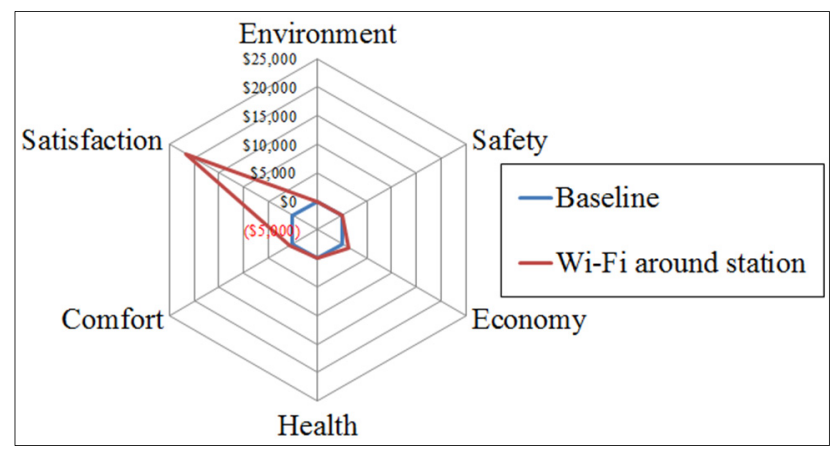

Figure 6. Estimated impact of Wi-Fi around station based on proposed KPIs.

\subsection{Information Transmission and Control}

We used one EPSON/ Endeavor AT980E as the ICT server for information transmission and control. Its lifetime was assumed to be five years. The GHG emissions from its manufacture were estimated using the process LCA data, those from its operation were estimated using rated power, and those from disposal were estimated using Japanese I-O table values for waste treatment. The GHG emissions from its manufacture and disposal were allocated considering its lifetime. Table 16 lists the LCA results of the ICT system for IP announcements. The annual GHG emissions from this ICT system were estimated to be $762 \mathrm{~kg}-\mathrm{CO}_{2} \mathrm{e} /$ year considering the product's life cycle.

Table 16. Annual GHG emissions of ICT system for information transmission and control $\left(\mathrm{kg}-\mathrm{CO}_{2} \mathrm{e} /\right.$ year$)$.

\begin{tabular}{ccccc}
\hline & Manufacture & Operation & Disposal & Total \\
\hline Server & 19.2 & 128 & -2.6 & 144 \\
Total & 19.2 & 128 & -2.6 & 144 \\
\hline
\end{tabular}

Decrease in cost of evacuation time was estimated using Equation (6). Table 17 lists the parameters and calculated results on decrease in cost of evacuation time.

Decrease ion cost of evacuation time $=$ Decreased time $\times$ User number $\times$ Minimum hourly wage $\times$ Annual possible number of strong earthquakes

Table 17. Parameters and calculation results of decrease in cost of evacuation time.

\begin{tabular}{lcl}
\hline \multicolumn{1}{c}{ Parameter } & Amount & \multicolumn{1}{c}{ Note } \\
\hline Decreased time & $40 \mathrm{~min} /$ disaster & Assumption of study \\
\hline Number of users & 166,284 & Assumption of study \\
\hline $\begin{array}{l}\text { Minimum hourly } \\
\text { wage (Japan) }\end{array}$ & $\$ 7.8 / \mathrm{h}$ & $\begin{array}{l}\text { Weighted average of local minimum hourly } \\
\text { wage in Japan } \\
\text { Note: refer to Table } 14\end{array}$ \\
\hline $\begin{array}{l}\text { Annual possible number of } \\
\text { strong earthquakes }\end{array}$ & 0.1 times/year & $\begin{array}{l}\text { Annual possible number of earthquakes in } \\
\text { Tokyo measuring }>5 \text { on Japanese } \\
\text { earthquake intensity scale of one to seven } \\
\text { Note: refer to Table 14 }\end{array}$ \\
\hline $\begin{array}{l}\text { Decrease in cost of } \\
\text { evacuation time }\end{array}$ & $\$ 86,500 /$ year & Calculated using Equation (6) \\
\hline
\end{tabular}

To consider the impact on the economy, we focused on the cost balance of information transmission and control (see Table 18). 
Table 18. Increased cost of information transmission and control.

\begin{tabular}{cccl}
\hline Increase/Decrease & Cost Category & $\begin{array}{c}\text { Annual Cost } \\
\text { (USD/Year) }\end{array}$ & \multicolumn{1}{c}{ Note } \\
\hline \multirow{2}{*}{ Increase } & $\begin{array}{c}\text { System } \\
\text { construction }\end{array}$ & 79.4 & $\begin{array}{l}\text { Total cost of server allocated by lifetime } \\
\text { Note: Assumed cost was \$396.9 for } \\
\text { EPSON/Endeavor AT980E }\end{array}$ \\
\hline \multirow{2}{*}{ Increase } & $\begin{array}{l}\text { Operation cost } \\
\text { for Mitaka city }\end{array}$ & 40.1 & $\begin{array}{l}\text { Annual power consumption of server } \\
\text { Note: Assumed cost of electricity was } \\
\$ 0.16 / \mathrm{kWh}\end{array}$ \\
\hline & Total & 119 & \\
\hline
\end{tabular}

To assess the impact on user satisfaction, we focused on the user's WTP for information transmission and control. The users' satisfaction was estimated using Equation (4). Table 19 shows the parameters used and the calculated result of users' satisfaction with information transmission and control.

Table 19. Parameters and calculation results of user satisfaction with information transmission and control.

\begin{tabular}{ccc}
\hline Parameter & Amount & Note \\
\hline Averaged WTP & $\$ 31.9$ month/user & $\begin{array}{c}\text { Obtained from questionnaire } \\
\text { Note: refer to Table 11 }\end{array}$ \\
\hline Number of users & 166,284 & Assumed based on study \\
\hline $\begin{array}{c}\text { Assumed annual revenue due to } \\
\text { user satisfaction }\end{array}$ & $\$ 6,360,000 /$ year & Calculated using Equation (4) \\
\hline
\end{tabular}

Figure 7 shows the estimated impact of information transmission and control based on the second layer of the proposed KPIs and the baseline defined as status quo. Compared with the baseline, information transmission and control was expected to offer the largest improvement in satisfaction in terms of assumed revenue, as much as $\$ 6,360,000$, and the second largest improvement was safety, around $\$ 90,000$. On the other hand, the estimated negative value on economy was nearly $\$ 100$ but the negative impact on the environment was negligible compared to the economy value and other positive values. This means that the impact of information transmission and control was significant in terms of satisfaction and safety rather than economy and environment. In addition, the summation value of all KPIs was around $\$ 3000$ in the positive. This result suggests that information transmission and control has a positive impact of as much as $\$ 6,450,000$ per year from the viewpoint of the triple bottom line.

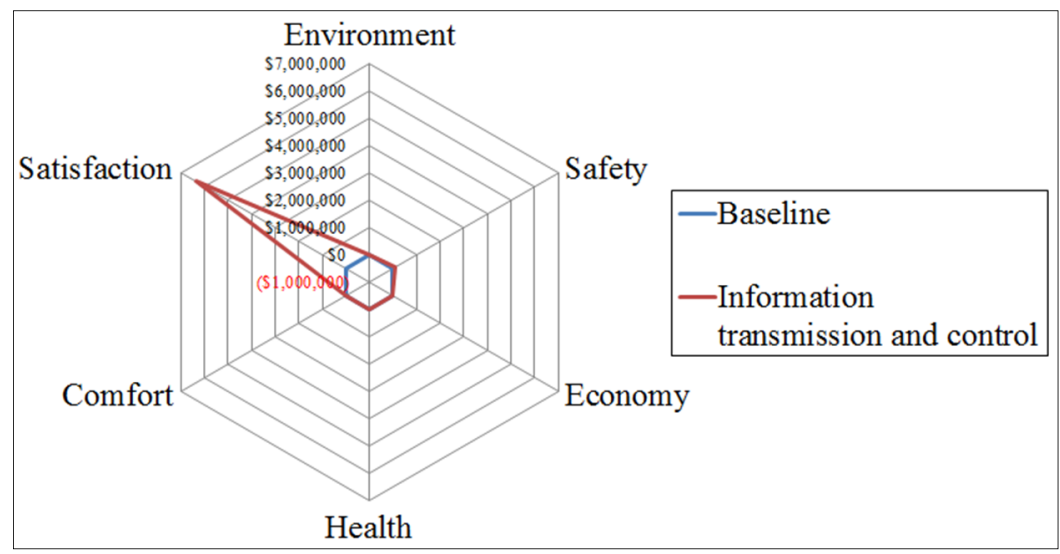

Figure 7. Estimated impact of information transmission and control based on proposed KPIs. 


\section{Conclusions}

We proposed a set of KPIs for SSCs and evaluated the effectiveness of proposed KPI and its assessment methodology through three case studies, "IP announcements", "Wi-Fi around station", and "information transmission and control" by assessing the improvement and decrease of environment, society and economy provided by individual ICT solutions deployed in SSCs. The results of all three case studies showed that the total KPI values improved, whereas each KPI value differed depending on each service. For example the KPI of satisfaction showed strong relationship with the assumed number of users, but the results showed that the estimated KPI did not seem to cause any conflict within the three individual ICT services. We suppose that this KPI and assessment methodology is applicable to SSCs when entire ICT solutions in it would be able to assess. However, some limitations were left in this study. Firstly, the synergy effect between ICT solutions was not a concern in this assessment methodology. When this method is applied to assess SSCs, the improvement and decrease impact would be summation of improvement and decrease impact by individual ICT solutions, not multiplier effect. If the synergy effect between ICT solutions were clarified, the synergy effect is able to estimate by treating it as a characteristic of the ICT solution. Secondly, this method is not able to assess the long term vision and strategy of SSCs. Instead, the distant-to-target weighting would be applicable when SSCs address numeric goals for KPI , based on long term vision and strategy. Thirdly, this assessment method demands much more numbers of case study for practical use. This assessment procedure left some extent of flexibility in order to improve the assessment methodology, especially the lower layer.

For a further study, we would improve the assessment method by implementing more case studies so as to contribute for SSCs to address shared and sound definition and long term strategy, based on proposal KPI.

Author Contributions: Jiro Nakamura and Shinsuke Hannoe designed the research; Minako Hara and Tomomi Nagao conducted the research and analyzed the data; and Minako Hara wrote the paper. All authors have read and approved the final manuscript.

Conflicts of Interest: The authors declare no conflict of interest.

\section{References}

1. United Nations, Department of Economics and Social Affairs, Population Division. World Urbanization Prospects; 2014 revision; United Nations: New York, NY, USA, 2015; pp. 1-3.

2. Komninos, N. Intelligent Cities: Innovation, Knowledge Systems, and Digital Spaces; Spon Press: London, UK, 2002; pp. 1-15.

3. Komninos, N. Intelligent Cities and Globalisation of Innovation Networks; Routledge: Oxon, UK, 2008; pp. 1-4.

4. Appel, S.U.; Botti, D.; Jamison, J.; Plant, L.; Shyr, J.Y.; Varshney, L.R. Predictive analytics can facilitate proactive property vacancy policies for cities. Technol. Forecast. Soc. Chang. 2014, 89, 161-173. [CrossRef]

5. Kulawiak, M.; Lubniewski, Z. SafeCity-A GIS-based tool profiled for supporting decision making in urban development and infrastructure protection. Technol. Forecast. Soc. Chang. 2014, 89, 174-187. [CrossRef]

6. Namdeo, A.; Tiwary, A.; Dziurla, R. Spatial planning of public charging points using multi-dimensional analysis of early adopters of electric vehicles for a city region. Technol. Forecast. Soc. Chang. 2014, 89, 188-200. [CrossRef]

7. Spickermann, A.; Grienitz, V.; von der Gracht, H.A. Heading towards a multimodal city of the future?: Multi-stakeholder scenarios for urban mobility. Technol. Forecast. Soc. Chang. 2014, 89, 201-221. [CrossRef]

8. Dacko, S.G.; Spalteholz, C. Upgrading the city: Enabling intermodal travel behavior. Technol. Forecast. Soc. Chang. 2014, 89, 222-235. [CrossRef]

9. Salcedo-Sanz, S.; Cuadra, L.; Alexandre-Cortizo, E.; Jiménez-Fernández, S.; Portilla-Figueras, A. Soft-Computing: An innovative technological solution for urban traffic-related problems in modern cities. Technol. Forecast. Soc. Chang. 2014, 89, 236-244. [CrossRef] 
10. Steenbruggen, J.; Nijkamp, P.; van der Vlist, M. Urban traffic incident management in a digital society: An actor-network approach in information technology use in urban Europe. Technol. Forecast. Soc. Chang. 2014, 89, 245-261. [CrossRef]

11. Akçura, M.T.; Avci, S.B. How to make global cities: Information communication technologies and macro-level variables. Technol. Forecast. Soc. Chang. 2014, 89, 68-79. [CrossRef]

12. Graham, S.; Marvin, S. Telecommunications and the City: Electronic Spaces, Urban Place; Routledge: London, UK, 1996.

13. Hollands, R.G. Will the real smart city please stand up? Intelligent, progressive or entrepreneurial? City 2008, 12, 303-320. [CrossRef]

14. Dameri, R.P. Smart City and Value Creation. In Smart City; Springer: Cham, Switzerland, 2014; pp. 1-12.

15. Deakin, M. Smart Cities; Routledge: Oxon, UK, 2014; pp. 1-12.

16. Vinod Kumar, T.M. E-Governance for Smart Cities; Springer: Singapore, Singapore, 2015; pp. 1-43.

17. Kitchin, R. Making sense of smart cities: Addressing present shortcomings. Camb. J. Reg. Econ. Soc. 2015, 8, 131-136. [CrossRef]

18. ITU-T Focus Group Technical Specifications. Overview of Key Performance Indicators in Smart Sustainable Cities; International Telecommunication Union: Geneva, Switzerland, 2014.

19. Nakamura, M.; Takahashi, K.; Nishi, S.; Kamekura, M.; Takeshima, M. Lifecycle inventory study of teleconference system. In Proceedings of the Fourth International Conference on EcoBalance, Tsukuba, Japan, 31 Octber-2 November 2000; pp. 529-532.

20. Caudill, R.J.; Yanchun, L.; Wirojanagud, P.; Zhou, M. A lifecycle study of the impact of e-commerce on electronic products. In Proceedings of the International Symposium on Electronics and the Environment, San Francisco, CA, USA, 8-10 May 2000; pp. 298-303.

21. Herring, H.; Roy, R. The rebound effect, sustainable consumption and electronic appliances. In Proceedings of the Sustainability in the Information Society: 15th International Symposium Information for Environmental Protection, Zurich, Switzerland, 10-12 October 2001; Volume 2, pp. 870-876.

22. Takahashi, K.I.; Nakamura, J.; Kunioka, T.; Nishi, S. Life cycle inventory analysis of teleconference system. In Proceedings of the Annual Symposium of Society of Environmental Science, Kusatsu, Japan, 19-21 September 2002; pp. 6-7.

23. Credé, M.; Sniezek, J.A. Group judgement process and outcomes in video-conferencing versus face-to-face groups. Int. J. Hum. Comput. Stud. 2003, 59, 875-897. [CrossRef]

24. Takahashi, K.I.; Kunioka, T. Environmental impact assessment for e-learning systems. In Proceedings of the Annual Symposium of Society of Environmental Science, Tokyo, Japan, 11-12 September 2003; pp. $92-93$.

25. Takahashi, K.I.; Nakamura, J.; Kunioka, T.; Nishi, S. Environmental impact assessment for information communication services. In Proceedings of the EcoDesign 2002 Japan Symposium, Tokyo, Japan, 5-6 December 2002; pp. 10-11.

26. Toffel, M.W.; Harvath, A. Environmental implications of wireless technologies: News delivery and business meetings. Environ. Sci. Technol. 2004, 38, 2961-2970. [CrossRef] [PubMed]

27. Takahashi, K.I.; Tatemichi, H.; Tanaka, T.; Nishi, S.; Kunioka, T. Environmental impact of information and communication technologies including rebound effects. In Proceedings of the IEEE International Symposium on Electronics and the Environment, Scottsdale, AZ, USA, 10-13 May 2004; pp. 13-16.

28. James, P. Results of a survey on its economic, environmental and social impacts. Available online: http://www.pbmc.coppe.ufrj.br/es/component/docman/doc_view/194-2006-james (accessed on 11 September 2015).

29. Takahashi, K.I.; Tsuda, M.; Nakamura, J.; Kato, K.; Nishi, S. Environmental assessment of e-learning based on a customer survey. In Proceedings of the EcoDesign 2005 Japan Symposium, Tokyo, Japan, 12-14 December 2005; p. 25.

30. Vanolo, A. Smartmentality: The smart city as disciplinary strategy. Urban Stud. 2014, 51, 881-896. [CrossRef]

31. Collection of Mitaka City statistics data. Available online: http://www.city.mitaka.tokyo.jp/c_service/011/ attached/attach_11863_2.pdf (accessed on 11 December 2015).

32. Collection of Mitaka City statistics data. Available online: http://www.city.mitaka.tokyo.jp/c_service/044/ attached/attach_44665_1.pdf (accessed on 11 December 2015). 
33. Actual Condition of Traffic Accident Detected from the Data on Automobile Insurance Published by the Genetal Insurance Association of Japan. Available online: http://www.sonpo.or.jp/archive/report/ traffic/pdf/0033/book_jikojittai2011.pdf (accessed on 11 December 2015).

34. Crime Statistics of Snatch Theft from Saitama Pref. Police. Available online: http://www.police.pref. saitama.lg.jp/c0011/kurashi/hittakuri-toukei1.html (accessed on 26 February 2016). (In Japanese)

35. Macromill, User Survey on Net Super Market. Available online: http://data.macromill.com/pdf/ 200908_netsuper.pdf (accessed on 11 September 2015). (In Japanese)

36. Japan Weather Association and ALiNK Internet, Earthquake information. Available online: http://www.tenki.jp/ bousai/earthquake/entries?order=\&desc=0\&max_level=level_5_minus\&p=6 (accessed on 14 December 2015).

37. Japan Ministry of Health, Labour and Welfare, List of Prefectural Minimum Wages in Japan. Available online: http://www.mhlw.go.jp/stf/seisakunitsuite/bunya/koyou_roudou/roudoukijun/minimumichiran/ (accessed on 14 December 2015). (In Japanese)

(C) 2016 by the authors; licensee MDPI, Basel, Switzerland. This article is an open access article distributed under the terms and conditions of the Creative Commons by Attribution (CC-BY) license (http://creativecommons.org/licenses/by/4.0/). 